\title{
The SNPfordD Assay as a Supplementary Method in Kinship and Trace Analysis
}

\author{
Thorsten Schwark Patrick Meyer Melanie Harder Jan-Hendrick Modrow \\ Nicole von Wurmb-Schwark
}

Institute of Legal Medicine, University Hospital Schleswig-Holstein, Kiel, Germany

\section{Keywords \\ SNP · Kinship · Snapshot · Multiplex PCR . \\ Paternity testing}

\section{Summary}

Objective: Short tandem repeat (STR) analysis using commercial multiplex PCR kits is the method of choice for kinship testing and trace analysis. However, under certain circumstances (deficiency testing, mutations, minute DNA amounts), STRs alone may not suffice. Methods: We present a 50-plex single nucleotide polymorphism (SNP) assay based on the SNPs chosen by the SNPforlD consortium as an additional method for paternity and for trace analysis. The new assay was applied to selected routine paternity and trace cases from our laboratory. Results and Conclusions: Our investigation shows that the new SNP multiplex assay is a valuable method to supplement STR analysis, and is a powerful means to solve complicated genetic analyses.

\section{Introduction}

Beginning in the mid-1980s, DNA analysis revolutionized routine forensic work such as kinship or trace investigations $[1,2]$. Shortly after genetic fingerprinting by restriction fragment length polymorphisms analysis (RFLP) was established, the polymerase chain reaction (PCR) was presented as a method for artificially amplifying specific DNA fragments [3]. With this method individual specific polymorphic short tandem repeats (STRs) could be detected. This enabled the analysis of even

\section{Schlüsselwörter}

SNP - Vaterschaft - Snapshot - Multiplex PCR .

Vaterschaftstestung

\section{Zusammenfassung}

Hintergrund: In der modernen Vaterschafts- und Spurenanalytik ist die Untersuchung sogenannter Short Tandem Repeats (STRs) heute das Mittel der Wahl. In bestimmten Fällen (Defizienzen, Mutationen in den STR-Systemen, sehr geringe DNA-Mengen) kann die STR-Analyse allein unter Umständen zur Klärung nicht ausreichen. Methoden: Wir stellen als zusätzliche Methode einen von uns auf Basis der vom SNPforlD-Konsortium vorgeschlagenen Single Nucleotide Polymorphisms (SNPs) entwickelten, 50 SNPs umfassenden Assay vor. Dieser neue Multiplex-Assay wurde in verschiedenen Routinefällen angewandt. Ergebnisse und Schlussfolgerungen: Unsere Untersuchungen zeigen, dass die SNP-Analyse eine wertvolle Ergänzung der STR-Untersuchung darstellt und geeignet ist, zur Lösung komplizierter Spuren- und Vaterschaftsfälle eingesetzt zu werden.

minute amounts of biological material, such as DNA from old or degraded skeletal specimens [4-7], putrefied tissues [8, 9], burned remains $[10,11]$ or forensically relevant traces, e.g. single hairs [12] or swabs from touched objects [13,14].

Today, STR analysis is also a powerful tool for kinship analysis $[15,16]$. Modern multiplex PCR kits allowing the amplification of 15 or 16 STRs simultaneously in 1 reaction [17, 18] usually provide the genetic information necessary for resolving most questions frequently encountered in paternity and relationship cases. According to the German guidelines,

\section{KARGER \\ Fax +497614520714 \\ Information@Karger.de}

www.karger.com 
the investigation of paternity cases by STR analysis alone is allowed as long as 12 genetic markers or their products are investigated [19]. Consequently, commercially available STR typing kits have become the preferred tool in kinship analysis and relationship testing, making paternity analysis much faster and also cheaper. Time consuming RFLP testing on the other hand has disappeared from most routine labs, leaving most expert witnesses without a second method even though a second system is recommended by German guidelines [20].

The sole application of STR analysis in paternity testing can be problematic in various ways, and might lead to ambiguous results: i) due to a low probability of relationship or when an exclusion of fatherhood is suggested by just 1 or 2 STR loci, e.g. when (unknowingly) testing close relatives of the alleged father; ii) in cases where only 1 of the alleged parents is available for testing (so-called deficiency cases), and STR results provide insufficient information for an exclusion; iii) because of the relatively frequently occurring germ-line step mutations in STR loci (addition or the diminution of 1 or 2 repeats; mutation rate between 0 and $7 \times 10^{-3}$ according to [21]) that cannot be distinguished from exclusions. Most laboratories supplement such cases with additional autosomal STR markers, alternative primer sets for STR systems that showed ambiguous results or, if applicable, Y chromosome STR typing. This can, however, lead to additional problems such as mutations in primer binding sites or additional ambiguous results, further hampering the resolution of these cases.

Single nucleotide polymorphisms (SNPs) have been extensively investigated in a forensic context in recent years. The use of SNPs in paternity testing has been described by Børsting et al. [22, 23]. SNPs rely on short amplicons (usually less than $100 \mathrm{bp}$ ), display a much lower mutation rate than STRs (approximately $10^{-8}$ [22]) and can be easily detected using the same laboratory equipment used for STR analysis. Since SNPs are much less polymorphic than STRs, the investigation of a high number of loci is necessary: approximately 4.2 SNPs with allele frequencies of 0.5 give the same power of exclusion as 1 STR locus [24], and 50 SNPs with allele frequencies of $0.2-0.8$ result in the same likelihood ratio as 12 STRs [25].

To resolve complicated paternity cases that cannot be settled by STRs alone, we decided to implement the SNPforID assay comprising 52 autosomal SNPs [26] as a supplementary method in our routine forensic genetic lab. After establishing and optimizing the new assay, we tested the usefulness of SNP typing on several routine cases that could not always be conclusively solved by STR analysis alone.

\section{Material and Methods}

Samples

In the implementation of the method and the sensitivity study, the commercially available standards 9948 male DNA and 9947A female DNA
(Promega, Mannheim, Germany) were used. Both were serially diluted to $1 \mathrm{ng} / \mu \mathrm{l}-15 \mathrm{pg} / \mu \mathrm{l}$. In addition, DNA extracted from blood samples donated voluntarily by lab personnel was investigated in the same way. To test the new assay for kinship analysis, we used DNA material from the routine collective of the Institute of Legal Medicine in Kiel. We only investigated paternity cases in which the participants had agreed to further scientific investigations according to the German law on genetic investigation (GenDG). 11 cases were chosen: 3 cases with high paternity indices for the alleged father, 3 cases with 1 mutation in at least 1 of the STR systems, and 5 cases in which the alleged father had been previously excluded through STR analysis. These exclusion cases were additionally simulated as motherless cases. To test the assay on routine trace analysis material, we also investigated highly degraded DNA samples from different cases (6 DNA samples from telogen hairs, DNA from putrefied tissues and buccal swabs from 3 different identification cases). All findings were compared with previously obtained STR-typing results using commercial multiplex-PCRs (AmpFlSTRIdentifiler ${ }^{\mathrm{TM}}$ (Applied Biosystems, Carlsbad, CA, USA), Powerplex 16 HS, Powerplex ESX and ESI (all Promega)).

\section{Methods of SNP Typing}

Of the 52 SNPs analyzed previously with the SNPforID assay, 2 polymorphisms could not be satisfactorily detected in our lab. The other 50 SNPs were included in our 50-plex assay as shown in detail in table 1. All primer sequences were taken from the paper by Sanchez et al. [26], and analyzed using the PubMed SNP database (www.ncbinim.nih.gov/ pubmed). They were additionally checked for primer dimers, hairpin structures, etc., using the primer 3.2 software (www.genome.wi.mit.edu/ cgi-bin/primer/primer3_www.cgi). The HPLC-purified primers were ordered from Biomers, Germany. Amplified fragments were between 59 and 115 bp long.

\section{Multiplex PCR}

The amplification of all 50 SNPs was performed in 2 Multiplex PCRs comprising 21 and 29 primer pairs, respectively. A Qiagen ${ }^{\circledR}$ Multiplex PCR kit (Qiagen, Hilden, Germnay) was used in a total volume of $25 \mu \mathrm{l}$ for each PCR, and contained $1 \mu \mathrm{l}$ DNA extract (1 ng DNA content in paternity cases, pure DNA extract from minute trace samples without prior DNA quantification, and various DNA concentrations for sensitivity experiments). Amplification was conducted with the following PCR program: denaturation at $95^{\circ} \mathrm{C}$ for $15 \mathrm{~min}$ followed by 35 cycles of $94{ }^{\circ} \mathrm{C}$ for $30 \mathrm{~s}, 60{ }^{\circ} \mathrm{C}$ for $90 \mathrm{~s}$ and $72{ }^{\circ} \mathrm{C}$ for $60 \mathrm{~s}$, and a final extension step with $60{ }^{\circ} \mathrm{C}$ for $30 \mathrm{~min}$ in a GeneAmp ${ }^{\circledR} \mathrm{PCR}$ system 9700 (Applied Biosystems).

\section{Detection of PCR Products on Polyacrylamide Gels}

To confirm PCR success we preferred to use the highly discriminative and more sensitive polyacrylamide gels (PAG) with subsequent silver staining rather than agarose gel electrophoresis. $5 \mu \mathrm{l}$ of each PCR product was separated on a PAG and detected using modified silver staining [27].

\section{Single-Base Extension}

PCR products were purified using ExoSAP-IT (Affymetrix) according to the manufacturer's protocol. Single-base extension (SBE) was done using the ABI PRISM ${ }^{\circledR}$ SNaPshot ${ }^{\mathrm{TM}}$ kit (Applied Biosystems) with $1 \mu \mathrm{l}$ of the respective PCR product in 2 separate reactions, analogous to the abovedescribed PCRs, in a total volume of $8 \mu \mathrm{l}$. The fragments were amplified in the following SBE program: 30 cycles at $96^{\circ} \mathrm{C}$ for $10 \mathrm{~s}, 50{ }^{\circ} \mathrm{C}$ for $5 \mathrm{~s}$ and $60{ }^{\circ} \mathrm{C}$ for $30 \mathrm{~s}$ in the same PCR machine. SBE products were purified using FastApp Thermosensitive Alkaline Phosphatase (Fermentas) according to the manufacturer's protocol.
Schwark/Meyer/Harder/Modrow/ von Wurmb-Schwark 
Table 1. SNPs investigated in this study. Chromosome locations, database numbers, alleles and frequency data as given by Sanchez et al. [26] are shown. Also given are the concentrations for every SNP in the first PCR; Standard 52-plex: concentrations according to Sanchez et al. [26]; Optimized 50-plex: concentrations showing the best results in our study

\begin{tabular}{|c|c|c|c|c|c|c|c|c|c|}
\hline SNP & Ch. & NCBI rs No. & TSC no. & Allele & $\begin{array}{l}\text { America } \\
\text { frequency }\end{array}$ & $\begin{array}{l}\text { Asia } \\
\text { frequency }\end{array}$ & $\begin{array}{l}\text { Europe } \\
\text { frequency }\end{array}$ & $\begin{array}{l}\text { Standard } \\
\text { 52-plex, } \mu \mathrm{mol} / 1\end{array}$ & $\begin{array}{l}\text { Optimized } \\
50 \text {-plex, } \mu \mathrm{mol} / 1\end{array}$ \\
\hline 1 & 1 & Rs1490413 & TSC0724193 & $\mathrm{A} / \mathrm{G}$ & $0.59 / 0.41$ & $0.46 / 0.54$ & $0.47 / 0.53$ & 0.06 & 0.13 \\
\hline 2 & 2 & Rs876724 & TSC0208870 & $\mathrm{C} / \mathrm{T}$ & $0.72 / 0.28$ & $0.46 / 0.54$ & $0.69 / 0.31$ & 0.02 & 0.10 \\
\hline 3 & 3 & Rs1357617 & TSC0496080 & $\mathrm{A} / \mathrm{T}$ & $0.85 / 0.15$ & $0.80 / 0.20$ & $0.65 / 0.35$ & 0.02 & 0.06 \\
\hline 4 & 4 & Rs2046361 & TSC1065282 & $\mathrm{A} / \mathrm{T}$ & $0.65 / 0.35$ & $0.70 / 0.30$ & $0.80 / 0.20$ & 0.03 & 0.15 \\
\hline 5 & 5 & Rs717302 & TSC0039610 & $\mathrm{A} / \mathrm{G}$ & $0.92 / 0.08$ & $0.83 / 0.17$ & $0.45 / 0.55$ & 0.04 & 0.10 \\
\hline 6 & 6 & Rs1029047 & TSC0253802 & $\mathrm{A} / \mathrm{T}$ & $0.61 / 0.39$ & $0.27 / 0.73$ & $0.37 / 0.63$ & 0.06 & 0.20 \\
\hline 7 & 7 & Rs917118 & TSC0229630 & $\mathrm{C} / \mathrm{T}$ & $0.10 / 0.90$ & $0.50 / 0.50$ & $0.50 / 0.51$ & 0.03 & $\mathrm{~N}$ \\
\hline 8 & 8 & Rs763869 & TSC0065968 & $\mathrm{C} / \mathrm{T}$ & $0.48 / 0.52$ & no data & $0.56 / 0.44$ & 0.09 & 0.10 \\
\hline 9 & 9 & Rs1015250 & TSC0097236 & $\mathrm{C} / \mathrm{G}$ & $0.55 / 0.45$ & $0.40 / 0.60$ & $0.15 / 0.85$ & 0.03 & 0.06 \\
\hline 10 & 10 & Rs735155 & TSC0027519 & $\mathrm{A} / \mathrm{G}$ & $0.38 / 0.62$ & $0.82 / 0.18$ & $0.41 / 0.59$ & 0.05 & 0.13 \\
\hline 11 & 11 & Rs901398 & TSC0177752 & $\mathrm{C} / \mathrm{T}$ & $0.39 / 0.61$ & $0.29 / 0.71$ & $0.34 / 0.66$ & 0.02 & 0.10 \\
\hline 12 & 12 & Rs2107612 & TSC1108144 & $\mathrm{A} / \mathrm{G}$ & $0.64 / 0.36$ & $0.75 / 0.25$ & $0.70 / 0.30$ & 0.05 & 0.08 \\
\hline 13 & 13 & Rs1886510 & TSC0904551 & $\mathrm{C} / \mathrm{T}$ & $0.85 / 0.15$ & no data & $0.50 / 0.50$ & 0.01 & 0.08 \\
\hline 14 & 14 & Rs1454361 & TSC0684657 & $\mathrm{A} / \mathrm{T}$ & $0.57 / 0.43$ & $0.62 / 0.38$ & $0.47 / 0.53$ & 0.02 & 0.03 \\
\hline 15 & 15 & Rs2016276 & TSC0326920 & $\mathrm{A} / \mathrm{G}$ & $0.91 / 0.09$ & $0.59 / 0.41$ & $0.79 / 0.21$ & 0.17 & 0.40 \\
\hline 16 & 16 & Rs729172 & TSC0028090 & $\mathrm{A} / \mathrm{C}$ & $0.23 / 0.77$ & $0.06 / 0.94$ & $0.38 / 0.62$ & 0.02 & 0.08 \\
\hline 17 & 17 & Rs740910 & TSC0105771 & $\mathrm{A} / \mathrm{G}$ & $0.92 / 0.08$ & $0.92 / 0.09$ & $0.57 / 0.43$ & 0.08 & 0.10 \\
\hline 18 & 18 & Rs1493232 & TSC0729796 & $\mathrm{A} / \mathrm{C}$ & $0.44 / 0.56$ & $0.39 / 0.61$ & $0.56 / 0.44$ & 0.07 & 0.10 \\
\hline 19 & 19 & Rs719366 & TSC0044147 & $\mathrm{C} / \mathrm{T}$ & $0.24 / 0.76$ & $0.15 / 0.85$ & $0.38 / 0.62$ & 0.06 & 0.10 \\
\hline 20 & 20 & Rs1031825 & TSC0334834 & $\mathrm{A} / \mathrm{C}$ & $0.60 / 0.40$ & $0.41 / 0.59$ & $0.30 / 0.70$ & 0.03 & 0.10 \\
\hline 21 & 21 & Rs722098 & TSC0050288 & $\mathrm{A} / \mathrm{G}$ & $0.17 / 0.83$ & $0.50 / 0.50$ & $0.86 / 0.14$ & 0.12 & 0.10 \\
\hline 22 & 22 & Rs733164 & TSC0023085 & $\mathrm{A} / \mathrm{G}$ & $0.26 / 0.74$ & $0.16 / 0.84$ & $0.34 / 0.66$ & 0.02 & 0.05 \\
\hline 23 & 10 & Rs826472 & TSC0557086 & $\mathrm{C} / \mathrm{T}$ & $0.70 / 0.30$ & $0.66 / 0.34$ & $0.44 / 0.56$ & 0.04 & 0.08 \\
\hline 24 & 21 & Rs2831700 & no data & $\mathrm{A} / \mathrm{G}$ & $0.42 / 0.58$ & $0.50 / 0.50$ & $0.62 / 0.38$ & 0.04 & 0.08 \\
\hline 25 & 14 & Rs873196 & TSC0202434 & $\mathrm{C} / \mathrm{T}$ & $0.30 / 0.70$ & $0.19 / 0.81$ & $0.37 / 0.63$ & 0.03 & 0.08 \\
\hline 26 & 16 & Rs1382387 & TSC0544547 & $\mathrm{G} / \mathrm{T}$ & $0.55 / 0.45$ & $0.40 / 0.60$ & $0.25 / 0.75$ & 0.02 & 0.08 \\
\hline 27 & 12 & Rs2111980 & TSC1113476 & $\mathrm{A} / \mathrm{G}$ & $0.69 / 0.31$ & $0.60 / 0.40$ & $0.56 / 0.44$ & 0.01 & 0.05 \\
\hline 28 & 8 & Rs2056277 & TSC1082757 & $\mathrm{C} / \mathrm{T}$ & $0.70 / 0.30$ & $0.75 / 0.25$ & $0.55 / 0.45$ & 0.03 & 0.10 \\
\hline 29 & 18 & Rs1024116 & TSC0247167 & $\mathrm{A} / \mathrm{G}$ & $0.37 / 0.63$ & $0.12 / 0.88$ & $0.50 / 0.50$ & 0.03 & 0.08 \\
\hline 30 & 6 & Rs727811 & TSC0062764 & $\mathrm{A} / \mathrm{C}$ & $0.30 / 0.70$ & $0.66 / 0.34$ & $0.61 / 0.39$ & 0.03 & 0.10 \\
\hline 31 & 1 & Rs1413212 & TSC0607362 & $\mathrm{A} / \mathrm{G}$ & $0.61 / 0.39$ & $0.47 / 0.53$ & $0.41 / 0.59$ & 0.05 & 0.10 \\
\hline 32 & 17 & Rs938283 & TSC0357388 & $\mathrm{C} / \mathrm{T}$ & $0.09 / 0.91$ & $0.17 / 0.83$ & $0.30 / 0.70$ & 0.03 & 0.05 \\
\hline 33 & 4 & Rs1979255 & TSC0925231 & $\mathrm{C} / \mathrm{G}$ & $0.38 / 0.62$ & $0.33 / 0.67$ & $0.35 / 0.65$ & 0.03 & 0.08 \\
\hline 34 & 9 & Rs1463729 & TSC0377760 & $\mathrm{A} / \mathrm{G}$ & $0.79 / 0.21$ & $0.48 / 0.52$ & $0.56 / 0.44$ & 0.04 & 0.10 \\
\hline 35 & 11 & Rs2076848 & TSC0022275 & $\mathrm{A} / \mathrm{T}$ & $0.38 / 0.62$ & $0.58 / 0.42$ & $0.49 / 0.51$ & 0.04 & 0.05 \\
\hline 36 & 3 & Rs1355366 & TSC0491662 & $\mathrm{A} / \mathrm{G}$ & $0.40 / 0.60$ & $0.95 / 0.05$ & $0.70 / 0.30$ & 0.05 & 0.10 \\
\hline 37 & 2 & Rs907100 & TSC0186810 & $\mathrm{C} / \mathrm{G}$ & $0.74 / 0.26$ & no data & $0.48 / 0.52$ & 0.04 & 0.08 \\
\hline 38 & 13 & Rs354439 & TSC0700528 & $\mathrm{A} / \mathrm{T}$ & $0.50 / 0.50$ & $0.58 / 0.42$ & $0.64 / 0.36$ & 0.05 & 0.08 \\
\hline 39 & 22 & Rs2040411 & TSC1056845 & $\mathrm{A} / \mathrm{G}$ & $0.75 / 0.25$ & $0.08 / 0.92$ & $0.71 / 0.29$ & 0.03 & 0.05 \\
\hline 40 & 7 & Rs737681 & TSC0033074 & $\mathrm{C} / \mathrm{T}$ & $0.56 / 0.44$ & $0.80 / 0.20$ & $0.58 / 0.42$ & 0.03 & 0.10 \\
\hline 41 & 21 & Rs2830795 & no data & $\mathrm{A} / \mathrm{G}$ & $0.88 / 0.12$ & $0.45 / 0.55$ & $0.67 / 0.33$ & 0.02 & 0.08 \\
\hline 42 & 5 & rs 251934 & TSC0220872 & $\mathrm{C} / \mathrm{T}$ & $0.26 / 0.74$ & $0.16 / 0.84$ & $0.42 / 0.58$ & 0.01 & 0.05 \\
\hline 43 & 21 & rs914165 & TSC0197658 & $\mathrm{A} / \mathrm{G}$ & $0.66 / 0.34$ & $0.27 / 0.73$ & $0.49 / 0.51$ & 0.07 & 0.05 \\
\hline 44 & 1 & rs10495407 & no data & $\mathrm{A} / \mathrm{G}$ & $0.11 / 0.89$ & $0.42 / 0.58$ & $0.29 / 0.71$ & 0.05 & 0.10 \\
\hline 45 & 9 & rs1360288 & TSC0501229 & $\mathrm{C} / \mathrm{T}$ & $0.70 / 0.30$ & $0.50 / 0.50$ & $0.50 / 0.50$ & 0.04 & 0.05 \\
\hline 46 & 10 & rs964681 & TSC0270699 & $\mathrm{C} / \mathrm{T}$ & $0.37 / 0.63$ & $0.23 / 0.77$ & $0.41 / 0.59$ & 0.03 & 0.12 \\
\hline 47 & 20 & rs1005533 & TSC0082071 & $\mathrm{A} / \mathrm{G}$ & $0.55 / 0.45$ & $0.60 / 0.40$ & $0.45 / 0.55$ & 0.03 & 0.05 \\
\hline 48 & 15 & rs8037429 & no data & $\mathrm{C} / \mathrm{T}$ & $0.58 / 0.42$ & $0.42 / 0.58$ & $0.62 / 0.38$ & 0.03 & $\mathrm{~N}$ \\
\hline 49 & 1 & rs 891700 & TSC0162577 & $\mathrm{A} / \mathrm{G}$ & $0.53 / 0.47$ & $0.53 / 0.47$ & $0.57 / 0.43$ & 0.04 & 0.10 \\
\hline 50 & 13 & rs1335873 & TSC0829150 & $\mathrm{A} / \mathrm{T}$ & $0.91 / 0.09$ & $0.28 / 0.72$ & $0.36 / 0.64$ & 0.03 & 0.08 \\
\hline 51 & 22 & rs1028528 & TSC0253071 & $\mathrm{A} / \mathrm{G}$ & $0.35 / 0.65$ & $0.65 / 0.35$ & $0.74 / 0.26$ & 0.02 & 0.04 \\
\hline 52 & 15 & rs1528460 & TSC0798410 & $\mathrm{C} / \mathrm{T}$ & $0.65 / 0.35$ & $0.36 / 0.64$ & $0.29 / 0.71$ & 0.06 & 0.10 \\
\hline
\end{tabular}

No data $=$ No information given in the mentioned paper; $\mathrm{SNP}=$ single nucleotide polymorphism; Ch. = chromosome, NCBI = National Center for Biotechnology Information; $r$ s = reference SNP; TSC = the SNP Consortium; $\mathrm{A}=$ adenine; $\mathrm{C}=$ cytosine; $\mathrm{G}=$ guanine; $\mathrm{T}=$ thymine; $\mathrm{N}=$ this primer was removed from our assay. 
Fig. 1. Checking of amplification success prior to single-base extension (SBE). Aliquots of $5 \mu \mathrm{l}$ of each PCR product from 6 different samples were separated on a PAG and detected using a modified silver staining. Left: Results from the 21-plex; right: the 29-plex amplicons. $\mathrm{NTC}=$ No template control, $\mathrm{L}=$ molecular weight marker (GeneRuler ${ }^{\mathrm{TM}}$ Low range DNA ladder, Fermentas GmbH, Germany).
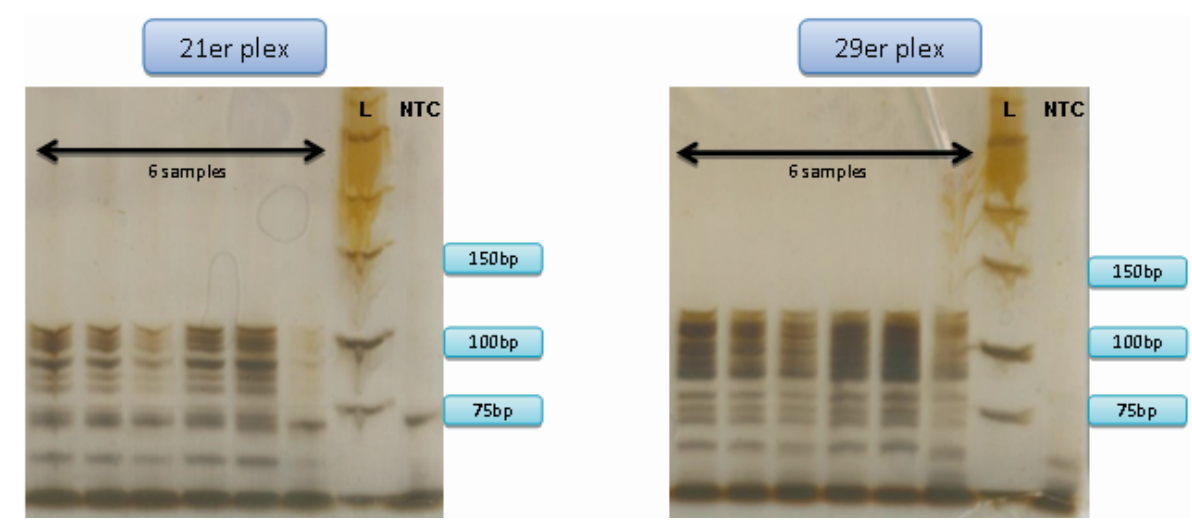

\section{Fragment Analysis}

Detection of SNP products was done on an ABI PRISM ${ }^{\mathrm{TM}} 3130$ Genetic Analyzer (Applied Biosystems) using $2 \mu \mathrm{l}$ purified SNaPshot product in $11.7 \mu \mathrm{l}$ HD formamide and $0.3 \mu \mathrm{l}$ LIZ120 standard (all Applied Biosystems). The data were processed using the GeneMapper ${ }^{\mathrm{TM}}$ ID Software version 3.2

\section{Biostatistical Calculations and Evaluations}

Probabilities of fatherhood and paternity indices were calculated according to Essen-Möller with a self-constructed software tool (PAnalyzer vers. 2.1) using European frequencies obtained from [26]. Calculation of genotype frequencies was made using the same frequencies and again a self-designed program (SNP-Ivers1.2). In this study all samples were analyzed using European frequencies; however, if the origin of the investigated persons was not European, Asian or American data could also be used and are part of our program.

\section{Results and Discussion}

\section{Sensitivity and Establishment of the Presented Assay}

Review of the published primer sequences uncovered 2 faulty primers: rs2076848 (SNP 35) and rs914165 (SNP 43) showed a wrong nucleotide sequence. The corrected sequences generated the expected fragments. 2 SNPs had to be removed from the assay: SNP 7 (rs917118) and SNP 48 (rs8037429) were not included in the multiplex PCR because they led to C artifacts that hampered the evaluation of other SNPs. To obtain a satisfactory detection threshold, the remaining 50 PCR products were generated in 2 different multiplex reactions (21- and 29plex). Figure 1 shows a PAG of different samples inserted into the 2 multiplex reactions.

In our approach the PCR conditions presented in [26] did not lead to a reliable and sensitive amplification. Most primer concentrations had to be increased (see table 1 for details). The application of the Qiagen Multiplex-PCR kit gave more robust and sensitive results compared to the $\mathrm{ImmoMix}^{\mathrm{TM}}$ (Bioline, Luckenwalde, Germany) and to a self-made PCR mix using Immolase (Bioline; data not shown). This necessary procedure is in accordance with studies from other groups such as that of Børsting and colleagues, who also reduced the number of SNPs from 52 to 49 and modified specific PCR conditions [23].

Fragment analysis conditions were also optimized to achieve signals between 1,000 and 6,000 relative fluorescence units (rfu). The use of $2 \mu \mathrm{l}$ SEB products led to strong and very clear signals. The chosen analysis conditions led to a detection threshold down to $500 \mathrm{pg}$ in dilution experiments using the 9947a female DNA (Promega), while 100 pg still allowed the detection of 36 out of 50 SNPs (72\%), and $25 \mathrm{pg}$ template DNA still led to 19 detectable SNPs (38\% success rate); see figure 2 for exemplarily results of a dilution experiment with the 29-plex.

Surprisingly, comparing the 2 SNP multiplex assays, we found that the 29-plex was more sensitive than the 21-plex. With $<500$ pg template DNA, significantly lower number of successfully amplified SNPs were found in the 21-plex. Using only 25 pg template DNA, approximately half of the 29 SNPs were still detectable, whereas only 5 SNPs were detected in the 21-plex (23\%). Keeping the multiplex assay separated in 2 different multiplex PCRs might be useful in cases in which template DNA is limited. In routine work it may be an option to use the 29-plex PCR first and then, depending on the outcome, subject the sample material to the less-sensitive 21-plex.

\section{Comparison of Routine Trace Analysis and Identification Cases}

After optimization, our SNP assay was used to investigate routine samples from various forensic cases. We initially chose 3 simple identification cases (severely putrefied bodies) that could not be solved by STR analysis. DNA was extracted from different soft tissues as previously described by our working group [9], and inserted into the assay. SNP detection worked very well even with DNA of low quality and quantity. As noted above, the 29-plex seemed to be more robust and reliable than the 21 SNP multiplex. In each of the 3 cases, ap- 
Fig. 2. Sensitivity of the established 29plex. Electropherogram after separation of specific reaction products on an ABI3130. Different DNA concentrations were subjected to the described 29-plex. The figure shows that with as little as $25 \mathrm{pg}$ template DNA some SNPs are still detectable.

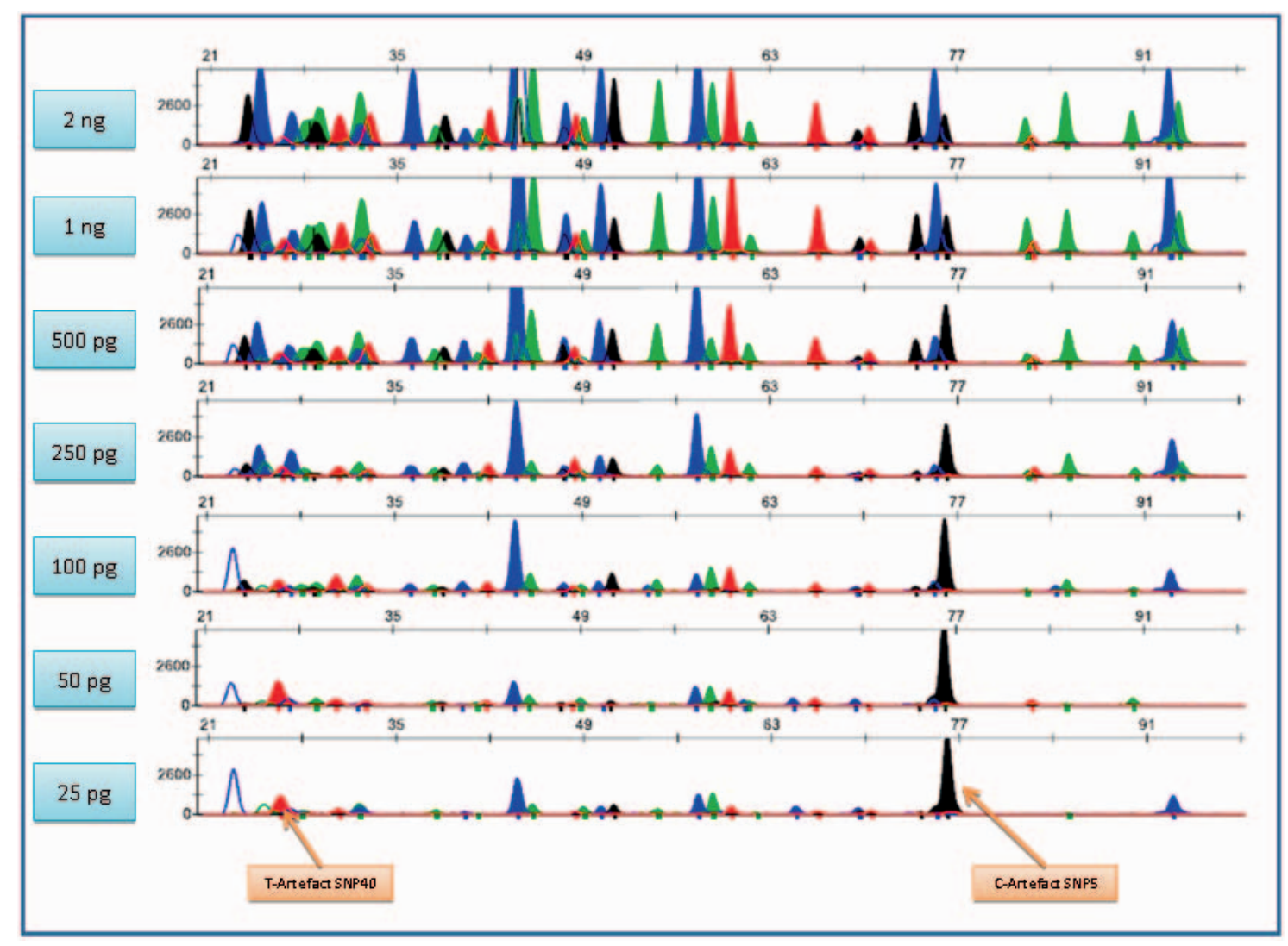

Fig. 3. Genetic analysis of single hairs using STR and SNP typing. Amplification success in percent of successfully typed markers after analyzing 17 STRs or 50 SNPs. Every analysis was done using $1 \mu \mathrm{l}$ pure DNA extract as template.

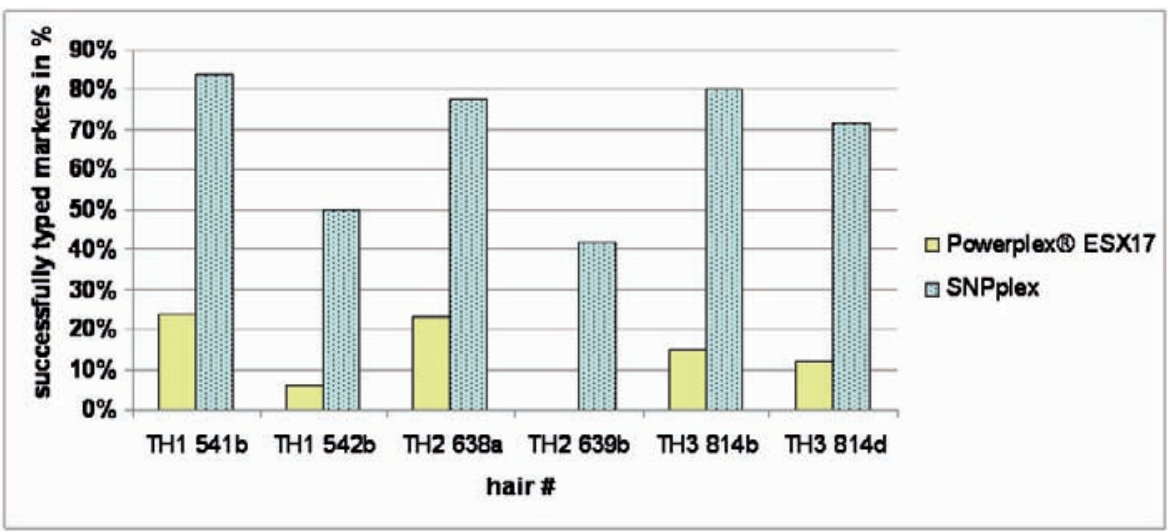

plication of our assay led to an adequate phenotype frequency that was comparable to the STR analysis results using the highly sensitive Powerplex ESX kit [18].

DNA extracted from 6 telogen hairs was then investigated and compared in the same way. Hairs with telogenic roots represent the majority of trace hairs collected in connection with criminal cases [12], and contain only little, if any, nuclear DNA [27]. SNP detection was successful in all 6 samples, while STR analysis gave no reproducible results in 1 of 6 cases. Furthermore, SNP typing led to higher phenoty pe frequencies than STR analysis. Again, the 29-plex gave a better amplification success than the 21-plex. We achieved a much higher amplification rate for our assay compared with STR typing using the Powerplex ESX17; whereas STR analysis yielded a maximum of 4 successfully amplified loci, our SNP-plex generated between 21 and 42 SNPs (see fig. 3 for a summary of the results). In conclusion, SNP typing provides a promising new tool for the analysis of minute and/or highly degraded DNA samples, and allows not only mitochondrial [28], but also autosomal investigation of degraded hair samples.

\section{Comparison of Different Paternity Cases}

We applied our assay in selected paternity investigations. In all cases, SNP-typing results were compared to those of STR analysis (amplification of 17 STRs using the Powerplex 16 HS and AmpFISTRIdentifiler multiplex PCR kits). 
Table 2. Results for paternity calculation using 17 STRs versus 50 SNPs. Values for combined paternity index and probability of paternity calculated using a self-developed software program

\begin{tabular}{|c|c|c|c|c|c|}
\hline \multirow[t]{2}{*}{ Case } & \multirow[t]{2}{*}{ Remarks } & \multicolumn{2}{|c|}{ Combined paternity index (PI) } & \multicolumn{2}{|c|}{ Probability of paternity (W), \% } \\
\hline & & 17 STRs & 50 SNPs & 17 STRs & 50 SNPs \\
\hline 1 & no mutations & $1.53 \times 10^{8}$ & $2.14 \times 10^{7}$ & >99.9999999 & 99.9999959 \\
\hline 3 & no mutations & $7.32 \times 10^{7}$ & $1.41 \times 10^{5}$ & $>99.999999$ & 99.9992925 \\
\hline 3 & no mutations & $5.13 \times 10^{7}$ & $2.35 \times 10^{6}$ & 99.999998 & 99.9999575 \\
\hline 4 & $\begin{array}{l}\text { 2-step paternal } \\
\text { mutation in } \\
\text { D2S1338 }\end{array}$ & $2.22 \times 10^{3}$ & $1.10 \times 10^{6}$ & 99.955068 & 99.999909 \\
\hline 5 & $\begin{array}{l}\text { 1-step paternal } \\
\text { mutation in FGA }\end{array}$ & $8.71 \times 10^{4}$ & $1.65 \times 10^{8}$ & 99.998851 & 99.9999994 \\
\hline 6 & $\begin{array}{l}\text { two 1-step } \\
\text { mutations, VWA } \\
\text { and Penta D }\end{array}$ & $3.22 \times 10^{1}$ & $6.32 \times 10^{8}$ & 96.990151 & 99.9999998 \\
\hline
\end{tabular}

\section{Trio Cases}

In all 3 regular trio cases (cases $1-3$ in table 2) involving mother, child and putative father, STR analysis gave higher combined paternity indices (PI) and probabilities of paternity (W) than SNP typing. However, SNP analysis alone was always sufficient to issue the highest verbal statement in Germany ('paternity practically proven') with W values above $99.9 \%$ (see table 2 for more detailed information). Our results support the findings of Børsting et al. [22] who calculated PIs between 489 and $6.31 \times 10^{8}$ with an average of $1.32 \times 10^{6}$ after investigating 72 Danish trio cases with 52 SNPs.

\section{Mutations}

STR analysis of 3 trio cases with mutations in different STR loci (cases 4-6 in table 2) gave lower combined PIs than investigation of the samples with our multiplex SNP assay. These results demonstrate one of the main advantages of SNP typing: the low mutation rate of approximately $10^{-8}$. STR analysis on the other hand can lead to false paternal or maternal exclusions due to a higher mutation rate and consecutive gain or loss of a limited number of tandem repeats, possibly as a result of slippage of the DNA replication complex during DNA synthesis [29]. Most common mutations using STR typing are false paternal or maternal exclusions, in which an obligate gene differs only slightly in its size from its presumed predecessor in an otherwise confirmed parent. This is unproblematic in cases with at least 3 mismatches that, according to guidelines, lead to the exclusion of the alleged father. In cases with less than 3 mismatches, the overall mutation rate of the investigated loci that ranges between $5 \times 10^{-4}$ and $7 \times 10^{-3}[21$, 30] can be used to calculate paternity probabilities. In this study, all 3 cases showed no mismatches after SNP typing. Thus, the additional investigation of SNPs always led to much higher and more reliable paternity probabilities. In 1 case with 2 mutations after STR analysis (case 6 in table 2), SNP typing was necessary to obtain the required $\mathrm{W}$ value of at least $99.9 \%$.

\section{Exclusions of Fatherhood}

Five trio paternity cases were chosen in which the alleged father was excluded via STR analysis. Investigation of 17 STRs resulted in 3-13 exclusions, while SNP typing $(n=50)$ led to an average of 7.2 exclusions (6-8). The results are in accordance with the calculations by Krawczak [24], who estimated that approximately 4.2 SNPs with allelic frequencies of 0.5 each give the same power of exclusion as 1 STR locus. We did not distinguish between genetic inconsistency and opposite homozygosity despite possible silent alleles; the latter is a strong indicator against paternity. In accordance with our results, Børsting et al. [22] found an average of 10 mismatches in their study.

\section{Deficiency Cases}

The above-mentioned 5 exclusion cases were additionally calculated as (simulated) deficiencies, i.e. without consideration of the mother. Analysis of 17 STRs resulted in 2-8 exclusions between child and alleged father. In 1 of the 5 cases the exclusion of fatherhood was not reliably possible. The supplementary application of our SNP assay, however, led to 3-8 additional excluding markers, reliably solving all cases. Recently, it was shown that in complicated cases (deficiencies, mutations/genetic inconsistencies) SNP typing was not only supportive, but even more informative than the analysis of 15 STRs in the 6 investigated cases [31].

\section{Conclusion}

Our study shows that the implementation of the SNP multiplex assay as a second method is a useful tool to increase the informative value of kinship and trace analyses, and that our assay comprising 50 SNPforID markers can be easily used as a standard method to confirm and complement STR results. The application of SNPs will frequently be suitable to differentiate between mere mutations and real exclusions in STR mismatch cases. Furthermore, our SNP assay will increase the reliability of results in deficiency cases. Under usual circumstances, the investigation of a large number of STRs provides 
a reliable paternity testing even without consideration of the mother. However, in cases with related alleged fathers (e.g. biological father and his full brother), false inclusions can occur [32]. Even an unrelated man might be falsely included [33]. In summary, the application of SNPs to supplement genetic analysis can be recommended, especially as no additional machinery is needed.

\section{Disclosure Statement}

The authors declare that there are no conflicts of interest regarding this publication.

\section{References}

1 Jeffreys AJ, Wilson V, Thein SL: Individual-specific 'fingerprints' of human DNA. Nature 1985; 316:76-79.

2 Jeffreys AJ, Wilson V, Thein SL: Hypervariable 'minisatellite' regions in human DNA. Nature 1985;314:673-73.

>3 Mullis K, Faloona F, Scharf S, Saiki R, Horn G, Erlich H: Specific enzymatic amplification of DNA in vitro: the polymerase chain reaction. Cold Spring Harb Symp Quant Biol 1986;51:263-273.

$\checkmark 4$ Hagelberg E, Gray IC, Jeffreys AJ: Identification of the skeletal remains of a murder victim by DNA analysis. Nature 1991;352:427-429.

$\checkmark 5$ Jeffreys AJ, Allen MJ, Hagelberg E, Sonnberg A: Identification of the skeletal remains of Josef Mengele by DNA analysis. Forensic Sci Int 1992; 56:65-76.

6 Alonso A, Andelinović A, Martin P, Sutlović D, Erceg I, Huffine E, de Simón LF, Albarrán C, Definis-Gojanović M, Fernández-Rodriguez A, García P, Drmić I, Rezić B, Kuret S, Sancho M, Primorac D: DNA typing from skeletal remains: evaluation of multiplex and megaplex STR systems on DNA isolated from bone and teeth samples. Croat Med J 2001;42:260-266.

7 Whitaker JP, Clayton TM, Urquhart AJ, Millican, Downes ES, Kimpton CP, Gill P: Short tandem repeat typing of bodies from a mass disaster: high success rate and characteristic amplification patterns in highly degraded samples. Biotechniques 1995;18:670-677.

8 Sato Y, Motani H, Inoue H, Hayakawa M, Yajima D, Nagasawa S, Kobayashi K, Saot K, Otsuka K, Iwase H: Multiplex STR typing of aortic tissue from unidentified cadavers. Leg Med 2009;11:455457.

9 Schwark T, Heinrich A, von Wurmb-Schwark N: Genetic identification of highly putrefied bodies using DNA from soft tissues. Int J Legal Med 2011; 125:891-894.

10 Schwark T, Heinrich A, Preusse-Prange A, von Wurmb-Schwark N: Reliable genetic identification of burnt human remains. Forensic Sci Int Genet 2011;5:393-399.

11 Meyer HJ: The Kaprun cable car fire disaster aspects of forensic organisation following a mass fatality with 155 victims. Forensic Sci Int 2003;138: $1-7$.
12 Hellmann A, Rohleder U, Schmitter H, Wittig H:
STR typing of human telogen hairs - a new approach. Int J Legal Med 2001;114:269-273.

13 Wickenheiser RA: Trace DNA: a review, discussion of theory, and application of the transfer of trace quantities of DNA through skin contact. J Forensic Sci 2002;47:442-450.

14 Goray M, Mitchell RJ, van Oorschot RA: Investigation of secondary DNA transfer of skin cells under controlled test conditions. Leg Med 2010;12: 117-120.

15 Thomson JA, Ayres KL, Pilotti V, Barett MN, Walker JIH, Debenham PG: Analysis of disputed single-parent/child and sibling relationships using 16 STR loci. Int J Legal Med 2001;115:128-134.

16 Grubwieser P, Zimmermann B, Niederstätter H, Pavlic M, Steinlechner M, Parson W: Evaluation of an extended set of 15 candidate STR loci for paternity and kinship analysis in an Austrian population sample. Int J Legal Med 2007;121:85-89.

17 Chiurillo MA, Morales A, Mendes AM, Lander N, Tovar F, Fuentes A, Ramirez JL: Genetic profiling of a central Venezuelan population using 15 STR markers that may be of forensic importance. Forensic Sci Int 2003;136:99-101.

18 Poetsch M, Bayer K, Ergin Z, Milbrath M, Schwark $\mathrm{T}$, von Wurmb-Schwark N: First experiences using the new Powerplex® ESX17 and ESI17 kits in casework analysis and allele frequencies for two different regions in Germany. Int J Legal Med 2011;125:733-739.

19 Hoppe JD, Kurth R, Sewing KF: Richtlinien für die Erstattung von Abstammungsgutachten, Bekanntgabe der Herausgeber Bundesärztekammer. Dtsch Ärztebl 2002;10:665-667.

20 Deutsche Gesellschaft für Abstammungsbegutachtung (DGAB): Leitlinien für die Erstattung von Abstammungsgutachten. www.dgab.org/Website/ Aktuelles_files/Leitlinien_2008.pdf.

21 Brinkmann B, Klintschar M, Neuhuber F, Hühne J, Rolf B: Mutation rate in human microsatellites: Influence of the structure and length of the tandem repeat. Am J Hum Genet 1998;62:1408-1415.

22 Børsting C, Sanchez JJ, Hansen HE, Hansen AJ, Bruun HQ, Morling N: Performance of the SNPforID 52 SNP-plex assay in paternity testing. Forensic Sci Int Genet 2008;4:292-300.
23 Børsting C, Rockenbauer E, Morling N: Validation of a single nucleotide polymorphism (SNP) typing assay with 49 SNPs for forensic genetic testing in a laboratory accredited according to the ISO 17025 standard. Forensic Sci Int Genet 2009;4:34-42.

24 Krawczak M: Informativity assessment for biallelic single nucleotide polymorphisms. Electrophoresis 1999;20:1676-1681.

25 Gill P: An assessment of the utility of single nucleotide polymorphisms (SNPs) for forensic purposes. Int J Legal Med 2001;114:204-210.

26 Sanchez JJ, Phillips C, Børsting C, Balogh K, Bogus M, Fondevila M, Harrison CD, MusgraveBrown E, Salas A, Syndercombe-Court D, Schneider PM, Carracedo A, Morling N: A multiplex assay with 52 single nucleotide polymorphisms for human identification. Electrophoresis 2006;27: 1713-1724.

27 Hühne J, Pfeiffer H, Waterkamp K, Brinkmann B: Mitochondrial DNA in human hair shafts - existence of intra-individual differences? Int J Legal Med 1999;112:172-175.

28 Köhnemann S, Pennekamp P, Schmidt PF, Pfeiffer H: qPCR and mtDNA SNP analysis of experimentally degraded hair samples and its application in forensic casework. Int J Legal Med 2010;124:337342.

29 Meissner C, von Wurmb N: Sensitive detection of the 4977 bp deletion in human mitochondrial DNA of young individuals. BioTechniques 1998;25:652654.

30 Henke L, Henke J: Mutation rate in human microsatellites. Am J Hum Genet 1999;64:1473-1474.

31 Børsting C, Morling N: Mutations and/or close relatives? Six case work examples where 49 autosomal SNPs were used as supplementary markers. Forensic Sci Int Genet 2011;5:236-241.

32 von Wurmb-Schwark N, Mályusz V, Simeoni E, Lignitz E, Poetsch M: Possible pitfalls in motherless paternity analysis with related putative fathers. Forensic Sci Int 2006;159:92-97.

33 Poetsch M, Lüdcke C, Repenning A, Fischer L, Mályusz V, Simeoni E, Lignitz E, Oehmichen M, von Wurmb-Schwark N: The problem of single parent/child paternity analysis - practical results involving 336 children and 348 unrelated men. Forensic Sci Int 2006;159:98-103. 